\title{
Privacy, Porn, and Gay Sex Parties: The Carceral Governance of Homosexuality in Indonesia
}

\author{
Hendri Yulius Wijaya (D) \\ Independent Researcher, Jakarta 10230, Indonesia; hendri.yulius@gmail.com
}

\begin{abstract}
This article examines how the recent Indonesian Pornography Law renders homosexuality and/or homosexual acts intelligible to the Indonesia state and society by institutionalising them as criminal offences. By drawing on insights from queer studies and exploring the cases of gay arrests in the country, I demonstrate that certain same-sex sexual acts are more susceptible to criminalisation, especially when those acts blur the distinction between public and private. The deployment of the Pornography Law against gay people, together with the anti-LGBT media environment in the country, has carried consequences for LGBT individuals, particularly gay people, by making them visible, legible, and thus subject to state surveillance and control.
\end{abstract}

Keywords: homosexuality; LGBT; Indonesia; sexuality; carceral; sexual governance; pornography; Pornography Law; homophobia; queer studies

\section{Introduction}

Since late 2015, queer people, or what the Indonesian press popularly refers to as

Citation: Wijaya, Hendri Yulius. 2021. Privacy, Porn, and Gay Sex Parties: The Carceral Governance of Homosexuality in Indonesia. Laws 10: 87. https://doi.org/10.3390/laws 10040087

Received: 10 August 2021

Accepted: 12 November 2021

Published: 15 November 2021

Publisher's Note: MDPI stays neutral with regard to jurisdictional claims in published maps and institutional affiliations.

Copyright: (C) 2021 by the author. Licensee MDPI, Basel, Switzerland. This article is an open access article distributed under the terms and conditions of the Creative Commons Attribution (CC BY) license (https:/ / creativecommons.org/licenses/by/ $4.0 /)$. 'Lesbian, Gay, Bisexual, and Transgender (LGBT)' ${ }^{1}$, have attracted significant attention from the state and society (Wieringa 2019, p. 113; Wijaya 2019, p. 133). After a few decades of fragmented coverage in the local media (UNDP and USAID 2014, pp. 40-41), and with increased visibility of the domestic LGBT movement and same-sex marriage legislation in the U.S. and other Western countries, Indonesian government officials, politicians, conservative religious figures, and the media all made explicitly derogatory statements in the press about LGBT people in 2015 and 2016 (Wijaya 2020). They mainly associated LGBT people and activism with immorality, abnormality, threats to national culture and identity, and even a proxy war against Indonesia by Western countries (Wijaya 2020, p. 2). This anti-LGBT media environment has not only made the term 'LGBT' become "part of the everyday vernacular of Indonesians" (Wijaya 2019, p. 133) but has also amplified hostility toward LGBT Indonesians (Listiorini 2020).

Equally disturbing is the legal pathway pursued by the conservative Islamic profamily group, Family Love Alliance (Aliansi Cinta Keluarga, AILA) to propose a revision of the Criminal Code (Kitab Undang-Undang Hukum Pidana, KUHP) by the Constitutional Court (Makhamah Konstitusi, MK) in 2016. This challenge to the KUHP would criminalise consensual same-sex sex acts. Apart from AILA's attempt, a similar proposal to amend the KUHP and penalise homosexual practices had been under consideration by the House of Representatives (Dewan Perwakilan Rakyat, DPR) for some time (Lindsey 2019, p. 43). In June 2015, the Joko Widodo administration submitted a revised draft of the KUHP to the DPR (Butt and Lindsey 2018, p. 200), followed by further drafts in February 2017 and March 2018, respectively. Although it had undergone many revisions, the most recent KUHP draft still included the 'LGBT Article' (Article 495) that "would make it a criminal offence to perform 'indecent acts' (perbuatan cabul) with a person of the same sex in public"

1 To limit the scope of analysis, I only focus on gay people. In Indonesia, transgender people have also become subject to police prosecution for their engagement with street sex work, for instance. 
(Butt and Lindsey 2018, p. 203). Exploiting this legal opportunity to expedite LGBT criminalisation, the AILA specifically challenged the MK to expand the KUHP's Article 284 on adultery and Article 285 on rape to penalise all extra-marital sex and prohibit "indecent acts between any people of the same gender, regardless of their age" (Lindsey 2019, p. 43). The group argued that the existing KUHP is "a product of Dutch colonialism" (Butt 2019, p. 59) and therefore "too liberal" for Indonesian society (Wijaya 2020, p. 162), because Article 492 only outlaws "adults who engage in 'indecent activities' with a minor of the same gender" (Butt and Lindsey 2018, p. 198).

Apart from the KUHP at the national level, there are also local bylaws designed to police non-normative sexualities at the provincial level, usually known as 'Peraturan Daerah (Perda)'. Historically, the emergence of Perda was made possible by the decentralisation policy of the Reformation Era (1998 to present), allowing greater flexibility for provincial governments to enact their own regulations, and simultaneously opening up avenues for conservative Islamic groups to influence those regulations (see Robinson 2015; discussed below). Drawing on "certain interpretations of Islamic law" (Rinaldo 2013, p. 183), these bylaws regulate female dress codes, alcohol consumption, gambling, and non-normative sexualities, associating them with immorality. For instance, South Sumatra's Provincial Ordinance on the Eradication of Immoral Behaviour (No. 12/2002) and Palembang's City Ordinance on the Eradication of Prostitution (No. 2/2004) both outlaw homosexuality, along with prostitution, adultery, and alcohol consumption (UNDP and USAID 2014, p. 22). The National Women's Rights Commission (Komnas Perempuan) annual review of Perda listed 421 bylaws that were discriminatory against women and minority groups, including LGBT people, between 2009 and 2016 (Butt and Lindsey 2018, p. 68). Although these bylaws were "unevenly enforced" (Rinaldo 2013, p. 183), they "remain on the books" (Rinaldo 2013, p. 183), and hence are available to prosecute LGBT individuals and women.

Although the MK eventually rejected the AILA's proposal in 2017 (Yulius 2017b), the absence of a specific anti-homosexuality statute at the national level did not dissuade the police from arresting LGBT people, particularly gay people. In the anti-LGBT media environment, given that it takes so long to revise the KUHP (Butt and Lindsey 2018, p. 200) and the AILA petition had been unsuccessful, the police were only able to use what the available legislation offered them, that is, the Pornography Law (Law No. 44/2008 or Undang-Undang No. 44/2008 on Pornography). This Law not only regulates pornographic materials but also potentially provides for the prosecution of individuals who exhibit "public eroticism, seen by law enforcers as 'pornographic action' (pornoaksi)"2 (Lindsey 2019, p. 42).

Between 2016 and 2020, several cases of police raids on allegedly gay parties drew great media and public attention due to the press' sensational portrayals of these incidents. The crackdown began in November 2016 when police and a religious vigilante group stormed into a party and detained 13 men in South Jakarta (Human Rights Watch 2018, pp. 20-21). Later, a similar incident took place in November 2017, when police raided a party in Surabaya, East Java, arrested 14 men, and confiscated condoms, mobile phones, and a flash drive containing porn videos that saw the men charged under the Pornography Law (Human Rights Watch 2018, p. 21; Yulius 2017a). Another more extensive police raid occurred in an alleged gay sauna in North Jakarta when 141 men were arrested at an event dubbed 'The Wild One' (Human Rights Watch 2018, p. 24; Hutton 2017). Some intriguing details of the police raids are worth pointing out here. First, the gay sauna venue called Atlantis was located in the red-light district of Kelapa Gading in North Jakarta, alongside many other venues with suggestive names like the Playboy Sensation and massage parlours for straight men (Hutton 2017). However, these were not targeted. Second, as the result of the raid, a 25-year-old man was imprisoned for two years and three months under the Pornography Law that outlaws striptease performances in public (Hutton 2017). The police reportedly witnessed him being invited onto the stage by one of the strippers (Hutton

2 The origin of and debates surrounding the term 'pornoaksi' is discussed below. 
2017). While most of the detained men were later released, nine men were convicted under the Law (Hutton 2017). As of writing, the latest gay police swoop took place in the time of the COVID-19 pandemic. In September 2020, 56 men were arrested at a private sex party in an apartment building in Central Jakarta (Human Rights Watch 2020).

The above examples are not exhaustive, but what is critical to highlight here is how the Pornography Law has regularly been used to convict gay men involved in these events. Several reports from human rights organisations have also confirmed this problematic deployment of the Law against gay men (Human Rights Watch 2018, 2020; UNDP and USAID 2014). Police raids of private gay parties and saunas, alongside media reports about the presence of condoms and pornographic materials in these locations, have imbued a sense of urgency to curb homosexual behaviour, which is said to be widespread among the young adult generation. Amid the anti-LGBT media environment and without questioning the socio-cultural construction of heterosexual and reproductive sex as the most natural and normal sex, such arrests and media portrayals have only reified the long-held prejudice that gay men are sex-crazed.

The deployment of the Pornography Law to effectively criminalise gay sex parties brings to the fore the following questions: Given that homosexuality is an abstract category of identity/sexual orientation and that it is almost impossible to charge someone for 'being homosexual', under what circumstances do homosexual acts/behaviours become subject to or more susceptible to criminalisation under this Law? If the homosexual acts in question blur the distinction between public and private (the boundaries between which can be difficult to pin down), can the police's arbitrary use of the Pornography Law further enable the prosecution of activities taking place in contexts that are arguably far from public? As explained later in detail, Article 1 of the Pornography Law targets "performances in public [emphasis added] that contain obscenity or sexual exploitation that violates the moral norms in society" (cited in Lindsey 2019, p. 42). One argument from the police quoted in the media demonstrated how they considered a gay sex party, although held in a hotel room deemed a private domain, to be a public activity because it engaged more than two people and involved monetary transactions considered a marker of prostitution (BBC 2020). The organisers usually required financial contributions to pay for the room hire or as an entrance fee to the party.

While addressing the questions above, I also extend my analysis to argue that the codification of homosexual sex in the Pornography Law has contributed to the making and solidification of socio-cultural meanings around same-sex sexual relations or intimacies. It is important to note here that I do not position the Law as the sole contributor in creating and cementing homosexual or gay identity in Indonesia. Instead, following Foucauldian analysis of the production of sexual identity through knowledge apparatus (see Foucault 1978), along with legal scholars' examination of homosexuality and law (Gleeson 2007; Zanghellini 2013), I position the Pornography Law as one of the governance vectors that make homosexuality and/or homosexual acts intelligible to the state and society by codification in statute. As such, although the prosecution of gay people was arguably based on the determination of their activities as public (not private), the deployment of the Pornography Law against gay people, together with the anti-LGBT media environment, has carried consequences for LGBT individuals by making them more visible, intelligible, and thus subject to the state's surveillance and control.

Throughout this article, when discussing the impact of the Pornography Law on gay people, I use the term 'homosexuality and/or homosexual acts' because the Law itself uses the term in Bahasa Indonesia, 'homoseksual', which can ambiguously refer to 'the subject' (as in a homosexual individual or a gay person) and also to 'same-sex sexual activities/intimacies' (as in homosexual acts, expressions, or behaviours). To avoid repetition, I also often use the term 'same-sex practices or acts' to replace 'homosexual acts, expressions, or behaviours'. I hope the context will help readers to identify the reason behind why I deploy such terms. 
Drawing on insights from queer studies, this article seeks to show how the Pornography Law renders homosexuality and/or homosexual acts intelligible to the state and society by institutionalising it as a criminal offence. To begin, I highlight the specific forms of same-sex intimacies, relations, and practices that are most likely to be the target of prosecution under this statute, examining the state's carceral mechanism to regulate nonnormative sexualities, as demonstrated by emerging concerns of some U.S. feminists (e.g., Halley et al. 2019; Gruber 2020). Here, the term 'carceral' refers to "crime-and-punishment solutions" engaging legal and prosecutorial mechanisms (Halley et al. 2019, p. x; see also Bernstein 2018). I aim to problematise the notion of sexuality-both heterosexuality and homosexuality - as a coherent, unified, and uniform category, demonstrating that it consists of a wide array of desires, practices, relations, and institutions subject to different modes of state governance. For example, while sex with the opposite gender in public might also be subject to the Pornography Law, a heterosexual marriage ceremony is expected to be publicly celebrated.

Central to this sexual governance is the making and dividing of the public and the private arbitrarily using legal mechanisms in order to allow and disallow particular sexual practices, institutions, or relations in public. Consequently, those potentially-criminalised sexual practices are relegated to the private sphere, rendered invisible and thus, to some extent, unproblematic, so long as they remain in private. As a result, the notion of privacy as an individual right by which to exercise sexual conduct in the domestic space is insufficient to protect particular non-normative sexual subjects. Sex workers, gay men participating in sex parties, and public health outreach workers distributing condoms and sexual health information may be at a higher risk of prosecution under the Pornography Law, especially amidst the heightened anti-LGBT sentiment in Indonesia. This is primarily because their activities can be easily deemed as pornographic. Said differently, the criminalisation of particular homosexual behaviours in Indonesia so far has something to do with the divide of public vis-à-vis private, the good vis-à-vis bad sex, and the visible vis-à-vis invisible. All these binary oppositions are terrain where political contestations are battled out. Along this line, I would also argue that despite targeting the public acts of same-sex relations or intimacies, the codification of homosexuality and/or homosexual acts in the Pornography Law also carries consequences for LGBT Indonesians' lives $^{3}$, making them intelligible and susceptible to the state's surveillance and control.

To achieve the objectives above, I begin with a snapshot of queer studies as the linchpin of my analysis. I then move to discuss the historical development of sexual politics in Indonesia that led to the emergence of the Pornography Law. By applying insights from queer studies, the following section attempts to unpack how the Pornography Law governs homosexuality while making homosexuality a subject intelligible to the state.

\section{Queering Public and Private Sex}

Emerging in the 1990s in the U.S. academy, queer studies ${ }^{4}$ as a field or discipline is "tough to pin down" (Cossman 2021, p. 130) for its anti-normativity impulse (Ghaziani and Brim 2019, p. 3). It is, however, still possible to identify the foundational ground and commonalities across different strands of queer studies. In principle, anti-normativity, anti-identitarianism, and a deconstruction impulse (see Ghaziani and Brim 2019, p. 3) are its primary characteristics, enabling the field to critique and question the idea of coherent and fixed gender and sexual identities, as well as to challenge and resist "sexual regimes of normalisation" (Cossman 2021, p. 131). Driven by such critical inclinations, queer studies is attentive to how sexual normalisation shifts across time through various vectors

3 It is also important to note here that the Pornography Law also carries consequences for heterosexuals or non-LGBT people. The most recent example is the charge of Indonesian actress Dinar Candy under the Pornography Law for wearing a bikini in her street protest (CNN Indonesia 2021). I discuss the implication of the Law on heterosexuals in the conclusion of this article.

4 Wiegman (2019, p. 261) shows that queer theory is "a distinct genre of critical analysis that emerged largely in English departments in the U.S. university in the late 1980s" while queer studies is "an interdisciplinary project that is increasingly institutionalised in formal terms" in the academy. Since I speak about broader queer politics beyond literary studies, I use the term 'queer studies' throughout this article. 
of governance, whether legal, socio-cultural, political, or consumer culture, resulting in the inclusion of certain acts, identities, and subjects in what is considered normal or acceptable, and the expulsion of others into realms of abnormality, immorality, or even criminality.

Sexual normalisation involves sorting sexual acts and subjects into categories of good and bad. As one of the foundational thinkers in queer studies, in her 1982 landmark essay, "Thinking Sex: Notes for a Radical Theory of the Politics of Sexuality", Gayle S. Rubin introduced "the sex hierarchy" that depicts the construction of the "sexual value system" (Rubin [1984] 2007), drawing and enacting an imaginary line between good and bad sex. On the one hand, in the charmed circle, "good, normal, and natural" sexuality refers to "heterosexual, marital, monogamous, reproductive, and noncommercial" sex (Rubin [1984] 2007 , p. 159). ${ }^{5}$ Important to highlight here is that this value construction of normal sexuality is aligned with other aspects and practices that are "coupled, relational, within the same generation, and occur at home ... [without] pornography, fetish objects, sex toys of any sort, or roles other than male and female" (Rubin [1984] 2007, p. 159). On the other hand, on the outside of the charmed circle lie the defining contours of bad sex, the opposition of all the constitutive elements of good sex, such as "homosexual, unmarried, promiscuous, nonprocreative, or commercial" which may also be "masturbatory or take place at orgies ... casual, cross-generational lines, and may take place in 'public,' or at least in the bushes or the baths." (Rubin [1984] 2007, p. 160). Bad sex may also engage "pornography, fetish objects, sex toys, or unusual roles." (Rubin [1984] 2007, p. 160). Although explicitly identifying heterosexuality and homosexuality as one of the normative sorting bases, Rubin did not solely assign good and bad values based on the gendered object-choice of sexuality. More than this, Rubin demonstrated that since sexuality manifests in a wide array of practices, conducts, and relations, good and bad sex also depends upon the ways sexual practices are expressed, including the objects involved, the types of erotic relations, and the spaces where sexual activities take place. All the breaking down of sexuality into the various components above takes sexual normalisation out of the simple division of heterosexual and homosexual, to consider also the spatial logic of normalisation, or more precisely, the divide of the public and the private.

The production and naturalisation of private and public boundaries are also integral components of heteronormativity. In 1998, queer theorists Lauren Berlant and Michael Warner demonstrated that the heterosexualisation of the U.S. public culture was deeply anchored to the privatisation and domestication of sex and intimacies. In this process, queer public sex cultures-such as "explicit sexual materials, theatres, and clubs" (Berlant and Warner 1998, p. 551)_had been made to dissipate, for example, through zoning laws (ibid.). They further argued that heterosexuality, and thus all forms of sexuality, "is not a thing", but rather "widely differing practices, norms, and institutions" (Berlant and Warner 1998, p. 552). Said differently, in the case of heterosexuality, there is no single and coherent heterosexuality since its manifestations vary in practices and manifestations. Yet such a diversity of practices has gone largely unnoticed. They are masked under the very category of heterosexuality, which has been 'naturalised' in the public life via "the ideologies and institutions of intimacy" (Berlant and Warner 1998, p. 553), consequently positioning 'privacy' or 'private life' as the primary domain where sexual practices and relations are permitted for enactment.

Moreover, ideologies of intimacy operate through the separation of private sex and "personal life from work, politics, and the public sphere" (Berlant and Warner 1998, p. 553), positioning intimacy and personal life as "the privileged institutions of social reproduction,

\footnotetext{
5 While Rubin defined 'monogamy'as good sex and 'non-monogamy' as bad sex, Indonesian law permits polygamy for heterosexual couples, positioning it as morally unquestionable to some extent. The Marriage Law (Law No. 1/1974 or Undang-Undang No. 1/1974 on Marriage) allows "men whose religion permitted ... to marry another wife" (Rinaldo 2013, p. 45) under particular conditions, for example, if his wife is "unable to 'perform her function as a wife', is incurably ill, physically incapacitated, or is barren." (Butt and Lindsey 2018, p. 453). Many of those who supported the Pornography Law came from sections of conservative Islamic society that support polygamy. One of the staunch supporters of the Law is the Islamic political party, the Prosperous Justice Party (Partai Keadilan Sejahtera, PKS) (see Lindsay 2011, p. 183). Rinaldo (2013, p. 143) shows that "PKS family values do not exclude the possibility of polygamy."
} 
the accumulation and transfer of capital, and self-development" (Berlant and Warner 1998, p. 553) and muting the fact that heterosexuality is not always 'normative' in its manifestations. In this context, heterosexual intimacies can also be bolstered by nonnormative sexual practices. For example, married heterosexual couples who take part in swinging, while thwarting the ideal of monogamous marital coupledom and deriving pleasure from swinging, actually seek to maintain their marriages (Lewis 2021, p. 267). Put differently, swinging "improved their marriages" (Lewis 2021, p. 267), perhaps by fulfilling the social reproduction identified above. In another context, Indonesia's Marriage Law permits polygamy for the husband whose "existing wife is unable to "perform her function as a wife', is incurably ill, physically incapacitated, or is barren" (Butt and Lindsey 2018, p. 453; see also previous footnote above). For the above reasons, understanding the sexual normalisation process requires attending to the organisation of intimacy, privacy, and sexual practices as a form of governance that shields various manifestations of sexualities, particularly non-normative ones, from being spoken about and made visible outside of the private realm. Furthermore, thinking of sexuality as a form of governance also prompts us to examine the ways in which particular non-normative sexual practices are allowed to be incorporated into the state-sanctioned marital institution, such as the example of polygamy in Indonesia's Marriage Law.

Fast forward to the mid-2000s and the current moment, when queer studies has moved to grapple with the normalisation of homosexuality in U.S. public life. With its commitment to anti-normativity, queer studies challenges the assumption that the normalisation of gay, lesbian, and to some extent, transgender subjects automatically signals progress. Usually termed as "queer liberalism" (Eng et al. 2005, p. 10, see also Eng 2010, pp. 2-3), such queer inclusion through some legal citizenship means (for example, gay marriage) tends to rely on consumer culture (Eng et al. 2005, pp. 10-11), neoliberalism (Duggan 2003), privatisation and the legal institutionalisation of intimacy (Eng et al. 2005; Eng 2010), and abandoning the queer critique of family and marriage (Eng et al. 2005, p. 11). In the context of gender and sexuality politics, neoliberalism does not simply refer to the shrinking of welfare support from the state and market privatisation or liberalisation, but also the instillation of self-governance and responsibility for people to become entrepreneurs of their own destiny (see, among others, Duggan 2003; Gruber 2020; Rottenberg 2018).

Equally important, as gay and lesbian subjects become inherent parts of the nationstate and normative subjects (Puar 2007), the increased turn to law to address sexual harms-such as sex-based discrimination and sexual violence-causes sex and sexualities to be "(over)regulated" (Cossman 2021; see also Halperin and Hoppe 2017). This move ironically expands the state power to criminalise other non-normative sexual practices and/or relations, including sex work and HIV transmission (ibid.). Again, this snapshot from the U.S. illuminates the shifting and continuation of the sorting mechanism of good sex (invisible, domestic, monogamous, healthy, noncommercial, legally-sanctioned) and bad sex (visible, public, non-monogamous, dangerous, commercial, illegal), along with the persistent binary of public and private that haunts this division.

One important aspect that make the U.S. queer liberalism possible is the legal mechanism transforming the once immoral same-sex sexual conduct of sodomy into a form of intimacy and the private act of individuals worthy of the state's protection (Eng 2010). In 2003, the U.S. Supreme Court struck down state sodomy laws in Lawrence and Garner $v$. Texas for "about one-fourth of the states" (Thomas 2017, p. 396), as "the other three-fourths had already eliminated the sodomy laws" previously (Thomas 2017, p. 396). However, technically, when the U.S. sodomy laws were still in place, most states rarely enforced them, as this was seen as "impractical and invasive" to the citizen's private space (Thomas 2017, p. 396), that is, a violation of "private sexual autonomy" (Thomas 2017, p. 396). As some legal and sexuality scholars have observed, the criminalisation of same-sex sexual acts, however, also paved the way for the birth of the homosexual subject in law (Gleeson 2007) and the creation of certain social meanings surrounding homosexuality and/or homosexual acts (Zanghellini 2013). Although laws criminalising same-sex relations/intimacies are not 
the sole contributor to solidifying the homosexual identity, Aleardo Zanghellini (2013, p. 60) asserts that the nature of law "as an authoritative discourse making claims to truth, and its ability to shape our apprehension of the social and inflect our value judgments" about homosexuality leads us to "engage with law and its legal categories, including beyond the courtroom and police station, and including at the psychic and inter-subjective level of identity construction" (Zanghellini 2013, p. 60).

The eventual overruling of the U.S. state sodomy laws reveals at least three critical aspects of sexuality politics. First, it constitutes a move toward liberal individualism (Smith 2017), folding previously immoral same-sex sexual acts into "discourses of intimacy and family, as well as marriage and coupledom" (Eng 2010, p. 42). Later, the 2015 Obergefell v. Hodges Supreme Court marriage equality decision institutionalised homosexual relationships as a form of normative family and domestic institution. Second, what are usually perceived as anti-homosexuality regulations often target particular sexual acts, such as sodomy or sex in public, prompting us to critically examine the work of the shifting sorting mechanism of private and public in making certain same-sex sex acts a criminal offence. Third, despite targeting public acts of same-sex sexual relations, sodomy laws, in some contexts, "are likely to have had a disproportionate stigmatising effect" (Zanghellini 2013, p. 60), while concomitantly solidifying the homosexual identity (Gleeson 2007). The latter is mainly because sexual acts continue to constitute a primary basis of sexual identity. Queer activists have also recognised that sodomy laws were "increasingly used to control lesbians and gay men, who were targeted with undercover sting operations and who risked arrests in gay bars and cruising places, as well as in hotel rooms and in their own bedrooms" (Barclay et al. 2009, p. 9). Said differently, although unevenly enforced, sodomy laws have contributed to legally codifying same-sex sexual acts. This process has in turn made homosexual subjects and their acts more intelligible and visible to both the state and society while generating value and legal judgments of homosexuality.

In Southeast Asia, especially Singapore and Malaysia, the criminalisation of homosexuality through law has also targeted specific sexual conduct. Historically, such criminalisation goes back to the legacy of the British Empire in the form of the laws outlawing gross indecency between men that were transported to the colonies in Asia (Yulius et al. 2018, p. 183). While most former colonies have decriminalised homosexuality, Singapore and Malaysia have continued to hold on to these colonial relics (Yulius et al. 2018, p.183). In practice, the contemporary enforcement of sodomy laws reveals the persisting public and private divide, together with value judgements about homosexuality.

In particular, the Singapore example is illustrative. Singapore's Section 377A of the Penal Code criminalises "'gross indecency' between men, a provision vague enough to encompass conduct ranging from displays of public affection to private, consensual sexual intercourse" (Chua 2014, p. 37; Yulius et al. 2018, p. 153). As Chua (2014, p. 37-38) has noted, this statute, however, has rarely been enforced in "private, consensual situations", and is mainly deployed in "nonconsensual situations or cases involving minors". Further, she also highlights how gay men entrapped by police at cruising grounds were usually prosecuted "on the grounds of Section 354, which refers to the assault or use of criminal force with the intent to 'outrage modesty' (of the undercover officer)" (Chua 2014, p. 38). Nonetheless, this is not to say that queer people do not suffer from discrimination due to stigma and prejudice around homosexuality perpetuated by the discursive power of the gross indecency statute. In other words, the existence of Section 377A "institutionalises unequal rights and a lack of protection for all LGBT persons" (Tang 2017, p. 64), demonstrating its material effects on queer people. ${ }^{6}$

Michael Warner (2002, p. 23) has rightly acknowledged that "public and private are abstract categories for thinking about law". He also asserts that both categories are not always ready to be coded as such in practice, since the sorting process depends on "social contexts, kinds of feelings, and genres of language" (Warner 2002, p. 27). Having

6 For a discussion of the impact of Section 377A on queer Singaporeans, see (Tang 2017, pp. 64-65). 
considered that legal statutes never operate in a vacuum and "law materialises as a fluid expression of governance, authority and power" (Raj and Dunne 2021, p. 6), by drawing on the queer analytical lens above and analysing Indonesia's Pornography Law, the following sections examine how the Law enables the carceral governance of homosexuality and/or homosexual acts while producing particular social meanings surrounding it.

\section{Historicising Porn, Sexual Politics, and The Public-Private Divide}

As one of the few Muslim-majority democracies and a former Dutch colony (Wijaya 2020), Indonesia has never had a specific law criminalising homosexuality at the national level. After Indonesia's independence from the Dutch colonial regime in 1945, the new government adopted and applied the colonial criminal code or Wetboek van Strafrecht voor Nederlandsch-Indië (WvS), notably with only a few changes. ${ }^{7}$ This penal code, particularly Article 492, only outlaws "'indecent activities' with a minor of the same gender ... [with] up to five years' imprisonment" (Butt and Lindsey 2018, p. 186). Nevertheless, the absence of a specific law criminalising homosexual acts between adults does not mean that homosexual individuals have not suffered from stigma and discrimination. Although Indonesians with same-sex desires began to embrace gay and lesbian identities in the late 1970s and early 1980s, many of them still saw same-sex desire as a form of sickness, and media reports rarely offered positive portrayals of homosexuality (Boellstorff 2005; UNDP and USAID 2014). Society mostly saw the homosexual identity as an abnormality and as irreconcilable with local culture. At this juncture, many gay and lesbian Indonesians entered heterosexual marriages to become ideal Indonesian citizens. Such a tendency reflected the gender ideology of the authoritarian New Order (1966-1998) which promulgated and legitimised the traditional nuclear family as a societal foundation and marker of a citizen's ideal adulthood (Boellstorff 2005; Wieringa 2019). Through this gender ideology, women's roles were discursively redacted and positioned as wife and mother, with men as the head of the household and breadwinner (Suryakusuma 1996).

During the New Order, issues of sexual morality as a public concern targeted women's sexuality and non-marital heterosexuality (Wijaya and Davies 2019, p. 154), including pornography and prostitution (Barker 2015, p. 257). On the one hand, since the heterosexual family institution was perceived as society's foundation, the government focused on "the expression of non-marital heterosexuality ... [since] private sexual activities of unmarried heterosexual couples [were seen] as threatening to the heterosexual reproductive family principle" (Wijaya 2020, p. 51). On the other hand, the discourse of "public morality' (kesusilaan) was also increasingly utilised by the state to control materials deemed pornographic and immoral. In a broader sense, kesusilaan alludes to the societal moral codes (see Barker 2015, p. 254) ${ }^{8}$ widely accepted as socio-cultural norms. Under Article 281 and 282 of KUHP, pornography, or more precisely, the production and circulation of immoral materials, is considered a part of Crimes Against Morality (Kejahatan Terhadap Kesusilaan) (Barker 2015, p. 254).

Responding to the flourishing film industry, the government enforced the 1992 Film Law to prevent public order and morality disturbance. ${ }^{9}$ Under Article 40, any parties would be penalised if they deliberately distributed, showed, or exported any film and sound materials the Film Censorship Board (Lembaga Sensor Film) had disallowed from public screenings and distribution. In a similar vein, it is also illegal to circulate a film publicly "without it being submitted to the censors" (Barker 2015, p. 254). This film censorship policy was accompanied by the Presidential Decree 7/1994 (PP No. 7 Tahun 1994), in which sexually explicit materials also encompassed materials that could potentially "deteriorate, threaten, and oppose the common decency norms (norma-norma kesopanan

7 What is important to note here is that the changes from the Dutch Criminal Code to the Indonesian Criminal Code did not involve any clauses involving sexual activity.

8 For a historical explanation of the deployment of the term 'pornography' in Indonesia, see (Barker 2015), pp. 255-58.

9 For a more comprehensive discussion of the control of pornography and the media in the pre-New Order and New Order eras, see (Lindsay 2011, pp. 175-78). 
umum)" (Sasono 2004, p. 79). Despite this regulatory landscape, the fact that plenty of erotic films were allowed for screenings in the cinemas throughout the 1970s-1990s demonstrates the ambivalence and elasticity of the extent of the regulation in practice and the highly-arbitrary determination of which materials are considered to go against norms of decency. Intriguingly, several local popular films with gay, lesbian, and transgender female characters were allowed to be screened in public (Murtagh 2013).

Since Indonesia's transition into a more democratic regime, public morality discourse has increasingly and significantly occupied the government's attention and conservative religious groups. Popularly known as the 'reformasi' (reformation) period (1998 to present), the collapse of the New Order regime in 1998 was followed by efforts to democratise the country through enacting laws protecting citizens and the press. Nonetheless, this regime change also "opened avenues for religious conservatism, or political Islam and other socially conservative Islamic groups" (Wijaya 2019, p. 143) who acquired public support by generating moral panic about the deteriorating public morality in the technological era (Davies and Bennett 2015, p. 9). This political outcome is important to acknowledge because the New Order state had previously suppressed these conservative political Islamic groups to curb any potential opposition to the government (Rinaldo 2013, p. 13; Robinson 2015; Van Wichelen 2010). Following democratisation, since the early 2000s in particular, with the decentralisation allowing provincial governments to be autonomous in enacting policies, several provincial parliaments have passed local bylaws regulating women's clothing and mobility and penalising prostitution and male homosexual acts. This legal focus on sexuality was ostensibly driven by fear of and concerns for the nation's moral degradation, signified by "new modes of sexual expressions" (Barker 2015, p. 255) emerging in books, films, dances, magazines, Internet platforms, and other forms of popular culture that openly displayed erotic, sensual, and sexual expressions (Davies and Bennett 2015, p. 9). This move also signalled a sexual normalisation process, through which non-normative sexual expressions were legally policed and curbed from what was considered 'public'.

Further, as a response to the seeming liberalisation of sexual norms and moral codes, conservative Islamic groups and vigilante groups, like the Islamic Defenders Front (Front Pembela Islam, FPI), staged public protests against immoral public events, including the only queer film festival in Indonesia at the time, the Q! Film Festival, where they accused the organiser of promoting pornographic materials (Tempo 2010; Wijaya and Davies 2019, p. 163). Under the aegis of protecting national morality and preventing the further incursion of Western immorality (Rinaldo 2013, p. 113), these conservative groups championed the Anti-Pornography and Pornoaction Bill (Rancangan Undang-Undang Pornografi dan Pornoaksi, RUU APP). As explained briefly above, the RUU APP soon ignited public debates and controversies involving various stakeholders, including Islamic political parties, human rights activists, feminists, moderate and liberal religious groups, and artists.

The RUU APP transformed sexuality issues that were deemed private into a public concern and, in doing so, connected sexuality to a broader discourse of public and national morality. The result of this transformation was the expansion of the state's carceral power to criminalise various forms of sexual conduct when they were perceived as threatening to public morality and order. Crucially, the RUU APP utilised the highly arbitrary and abstract term 'public' (muka umum) to justify how certain sexual and/or erotic acts, if committed in public, could be considered pornographic and a criminal offence, because they threaten public morality.

First drawn up and then immediately shelved in the 1990s (Allen 2009), the RUU APP was reintroduced again to the Parliament in 2003 (Widyawati 2006, p. 19). Initially, the bill did not ignite intense public debates and was commonly perceived as "uncontroversial ... and similar in content to pornography elsewhere" (Allen 2009). In general, it defined pornography as "substances or mediums of communication that is made for the purpose of conveying concepts that exploit sex, obscenity and/or erotica" (cited in Allen 2009). Equally important, the discourse of public morality protection was explicitly articulated in the RUU APP's twofold aim, which was "to uphold and revere the dignity and values of a 
faithful and devout people in order to create a society that honours God Almighty" and "to protect, guide and provide moral and ethical instruction to society" (cited from Allen 2009). When the RUU APP was revised to include a broader definition of pornography, public controversies ensued.

In the 2004 revised RUU APP, the Parliament included the terminology of 'pornoaction' (pornoaksi), because the earlier definition of pornography was understood to be too narrow and insufficient in addressing the complex moral problems in reality. While the definition of pornography above was retained, the additional terminology 'pornoaction' loosely referred to "any deliberate actions of showing or demonstrating sexual exploitation, sexual indecency (kecabulan), and/or erotica in public" (Allen 2009). Without further explanation of what sexual exploitation, indecency, and erotica exactly meant, this specific clause of pornoaction was not only subject to subjective interpretation but was also supplemented by other clauses explicitly criminalising less sinister and common affectionate activities. Article 8 prohibited individuals from showing or exposing genitals, buttocks, and breasts in public. Article 10 forbade people from kissing on the lips (berciuman bibir) in public or requesting people to kiss in public. Equally absurd, Article 11 targeted and positioned erotic dance moves in public as a crime, while sports activities, most likely due to the suggestive body movements, are only to be conducted in sports areas. These prohibitions could lead to five to twelve years imprisonment and/or a fine. ${ }^{10}$ Subsequently, opponents of the RUU APP rejected these clauses due to their potential to intervene in the most private domain of citizens and threaten freedom of expression. I would also add that the explicit use of the term 'in public' can be identified as a form of sorting mechanism of public-private to govern what was acceptable and unacceptable in public, simultaneously generating the public-private divide in an arbitrary manner, as I will explain shortly.

In the February 2006 RUU APP draft, the bill "contained 93 articles, of which 20 dealt with pornography and six with pornoaction" (Lindsay 2011, p. 184). Jennifer Lindsay observes that the definition of pornoaction in this draft included

revealing 'certain sensual parts of the body'; nudity in public; kissing in public; erotic dancing or erotic movement in public; masturbation or simulating masturbation in public (including ordering children to do the same); having sex or performing sex-simulated movements in public (and ordering children to do the same); holding sex shows and sex parties, including those with children; watching sex shows and sex parties; and the funding, sponsoring, or provision of space or equipment for 'pornoaction', sex orgies or sex show.

Equally important, Lindsay also highlights some considerable changes in the bill from the 2006 February draft to the May draft in response to public reaction. For instance, the prosecution of kissing in public, and the word 'media', were eliminated in the May draft, which also made pornography "clearly ... a matter of public behaviour and morality" (Lindsay 2011, p. 185). The above provision shows how pornography and pornoaction can include 'live action' besides erotic/sexual portrayals in media.

Throughout the drafting and revision processes and public debates, feminists and activists argued that the RUU APP was also entangled within gender and ethnic structures. What was perceived as a pornographic activity or pornoaction was gendered and racialised, making the bill's opponents, particularly feminists, critical of its potential impacts on women's lives. Feminists saw that the clause that identified particular parts of a body as a source of sexual incitement (sensual parts of the body) would make women's bodies more vulnerable to criminalisation. In other words, a man who is bare-chested would not be marked as sexually charged, compared to a woman dressed the same. Society imbues certain body parts of women with different cultural meanings and moral values, compared to the body parts of men. Ascribing moral and social meanings to particular parts of bodies "make those parts of flesh exist socially" (Westbrook 2021, p. 23). In the early 2000s, coinciding with the emergence of the RUU APP was the popular female Dangdut singer,

10 All the articles of the RUU APP discussed above are cited in Jurnal Perempuan (Widyawati 2004, pp. 111-16). See also (Allen 2009). 
Inul Daratista, whose dance moves were perceived by the state as sexually provocative, urging conservative politicians and religious leaders to call for a more stringent regulation of pornography. It can perhaps be argued that Daratista's pelvic thrust was the genesis of the re-emergence of the RUU APP (Allen 2009). Another criticism came from Balinese and Papuan government and society leaders (Sari 2006, p. 9; Sawitri 2006, p. 41) who were concerned that the prohibitions could extend to and repress local artistic and cultural products, expressions, customs, and costumes (Pausacker 2008). All of this traditional richness could perhaps be deemed pornographic under the RUU APP.

Similarly intriguing is the explicit mention of homosexuality as a form of deviant behaviour that pornographic materials could encompass. While such an appearance might suggest the potential for greater policing of homosexuality, a critical question arises from the inclusion of such a broad identity category: Since it is almost impossible to charge someone for 'being homosexual' and it is challenging for the police to intrude into private spaces, in what ways could homosexual acts become more susceptible to criminalisation under this Law? This question is pertinent to ask since the anti-homosexual laws often target specific sexual activities, such as sodomy, as outlined in the previous section, while at the same time producing value and legal judgements about homosexuality and/or homosexual acts through making them criminal offences.

The contestations surrounding the RUU APP reveal at least two significant aspects of gender and sexuality politics related to homosexuality in Indonesia's democratic era. First, coterminous with Indonesia's democratisation is the production of "many controversies about gender and morality, of which pornography has been one of the more contentious" (Rinaldo 2013, p. 114). The RUU APP (informing the Pornography Law of 2008) and public morality discourses have become the sorting and governing mechanisms of the private and the public, organising how citizens should express their sexual activities and conduct. Second, the explicit mention of homosexual sex as a form of deviant behaviour in the Pornography Law might suggest the state's heightened awareness of homosexuality and/or homosexual acts. It can also be argued that the mention of the term 'homosexual' in the Law also reveals the state's attempt at making homosexual subjects and acts intelligible and legally present in Indonesia. The broad category of homosexuality or homosexual acts would prove challenging to criminalise, as it can manifest in various forms, as in innate desires, attractions, expressions, and relations that are not always visible to the public. This is, nevertheless, precisely where the highly arbitrary sorting mechanism of public-private operates to classify what kinds of homosexual behaviours are 'allowed' and which ones are criminalised or more vulnerable to criminalisation. The following section attempts to demonstrate how the Pornography Law was deployed to prosecute specific forms of homosexual intimacies and practices while at the same time making homosexuality and/or homosexual acts intelligible and visible to the state and the public.

\section{Governing and Making Homosexuality Intelligible through Pornography}

Although feminists and human rights groups challenged the RUU APP for its criminalisation of mundane activities and its control of women's bodies, the bill eventually came into force in September 2008 as the Pornography Law (Law No. 44/2008 or UndangUndang No. 44/2008 on Pornography) (Allen 2009). ${ }^{11}$ That the terminology of 'pornoaction' was removed from the Law has not automatically eliminated the Law's potential to penalise sexual/erotic conduct, practices, and expressions in public deemed to be against existing moral norms. Said differently, the pornoaction concept is still maintained in Article 1 of the Pornography Law (Lindsey 2019, p. 42), which preserves a broad definition of pornography to the point of including

11 To track the articles undergoing considerable changes from the RUU APP bill to the Pornography Law, see (Allen 2009; Lindsay 2011). 
[ ... ] pictures, sketches, illustrations, photos, writing, voice, sound, moving pictures, animation, cartoons, conversations, movements of the body, or other forms through a variety of communication media and/or performances in public that contain obscenity or sexual exploitation that violates the moral norms in society [emphasis added].

In a nutshell, the 2008 Pornography Law "contains 45 clauses in eight sections" (Lindsay 2011, p. 187), compared to the RUU-APP which "contained 93 articles, of which 20 dealt with pornography and six with pornoaction" (Lindsay 2011, p. 184), as described above. Two other important points in the Pornography Law are worth pointing out here. First, the Law extends criminalisation to "producers, providers, distributors and users, as well as those who appear as actors in pornography and live performers" (Lindsay 2011, p. 187). Second, the Law grants a policing role to the community in "reporting cases of production, distribution, ownership, or use of pornography" (Lindsay 2011, p. 187), allowing citizen-based surveillance and control over sexuality.

The reservation of the undefined term 'public' and 'moral norms in society', provides an opportunity for "police to harass almost any person involved in any form of sexual or erotic behavior" (Lindsey 2019, p. 42), including queer people gathering or "socialising in public venues such as bars or clubs" (Lindsey 2019, p. 42 see also Wieringa 2019). In addition, the similarly vague Article 4, explicitly outlawing any conduct that involves, "nakedness", "giving an impression of nakedness", or "displaying genitals" (Lindsey 2019, p. 42) can be conveniently deployed to arrest, for example, gay men in a sauna where their physical appearance may give an impression of nakedness by wearing a towel around the waist. The explanatory memorandum to Article 4 describes that 'giving an impression of nakedness' may mean "using a covering over body that still allows the sexual organs to be seen in an explicit fashion" (Lindsey 2019, p. 42). While these two Articles might notably have been used to criminalise gay people for allegedly having sex in a public space, it is also necessary to question why the notion of public is applied in a sauna or hotel room that is supposed to be a private domain.

The Pornography Law also extends its carceral governance by outlawing the production and distribution of pornography, the display of performance or expression alluding to nudity and/or pornography, the provision of commercial sexual activities, and the showing of pornographic materials to the public. All these prohibitions are explicated in the following Articles:

\section{Article 4 (1):}

Every person is prohibited from producing, creating, multiplying, duplicating, distributing, broadcasting, importing, exporting, offering, trading, renting out, or providing pornography that contains: sexual intercourse, including deviant sexual behaviour [defined in the elucidation to Article 4(1) as sexual activity with corpses, animals, oral sex, anal sex, and lesbian and homosexual subject/sex acts (homoseksual)] [emphasis added]; sexual violence; masturbation; nudity or the appearance of nudity; genitals; or child pornography.

Article 4 (2):

Every person is prohibited from providing pornography services, which:

(a) depict explicit nudity or expressions alluding to nudity [emphasis added];

(b) show explicit depiction of genitalia;

(c) exploit or showcase sexual activity [emphasis added];

(d) offer or promote, both directly or indirectly, sexual services [emphasis added].

Article 6:

Every person is prohibited from broadcasting, utilising, acquiring, or possessing pornography products [emphasis added], as defined in the Article 4(1), except for those bestowed with authority from regulations [explained in the elucidation to Article 
6 is that the prohibition excludes the ownership of those products for private use (untuk dirinya sendiri dan kepentingan sendiri)] [emphasis added].

Since the private use of pornography seems to be excluded from the above prohibitions, the central question arises as to what may be defined and classified as the private and the public. The stubborn binary of the private and the public upheld in these Articles offers a productive domain to further explore the carceral governance logic that allows and disallows specific sexual practices and sexualities.

Several reports from human rights organisations are correct in identifying and demonstrating the extent to which the Pornography Law has become a primary prosecutory mechanism to target gay people (see, among others, Human Rights Watch 2018, 2020; UNDP and USAID 2014). Yet the raids and arrests at gay sex parties further show that the sexual orientation of the individuals involved is not always sufficient to explain why they were prosecuted. Instead, as has been explained throughout this article about the persistent binary of public-private in shaping normative sexuality, the space where the sexual activities took place and the number of people involved or exposed to the acts might also contribute to criminalisation under the auspices of violating the moral norms of society. Here, I would argue that since the boundaries between the private and the public are difficult to pin down, the determination of public and private in these cases is highly arbitrary.

More than simply arguing that homosexuality and/or homosexual acts are a violation of Indonesian moral norms or decency, the police have contended that the individuals involved were 'exhibiting' (mempertontonkan) sexual activities. In the case of the raid on Jakarta's gay sex party in September 2020, Tubagus Ade Hidayat, the General Crime Director of the Greater Jakarta Metropolitan Regional Police (Direktur Kriminal Umum Polda Metro Jaya) reportedly asserted, "Sex between two people in a room is fine. Yet this activity involved many people and they saw each other" ("Kalau berdua di kamar dan melakukan hubungan seks tidak apa-apa. Ini kan banyak dan saling lihat") (BBC 2020). In a similar vein, the raid on the allegedly gay sauna, Atlantis, in May 2017, also revealed an analogous spatial logic. Although a communications professor who helped draft the Pornography Law, Ade Armando, reportedly said that the police's action "went well beyond the law's intent" (Hutton 2017) since "hotels are private places [and] the pornography law does not apply", the Pornography Law was still used to imprison a twenty-five-year-old man, OS, for his 'striptease performance'. Reportedly, when the police arrived, OS was being invited onto the stage by one of the strippers hired by the sauna for 'The Wild One' event night. Both incidents confirm that the definition of public does not always or only refer to the physical domain (e.g., a hotel or closed space like a sauna) or the number of people present at such a domain. Apart from the charges of showing sexual activity and/or nudity to each other, another intriguing aspect is the accusation of being involved in a striptease performance. In a group sex scene, it is obvious that every person in the event can see each other's nudity. However, the charge imposed to OS was not only inaccurate, but it also demonstrated how the Pornography Law conveniently extends its reach by labelling and classifying a person's behaviour to fit the loose definition of pornography in an arbitrary manner.

Further, under the Pornography Law, a gay sex party can be accused of promoting or involving commercialised sexual activity or pornographic materials (see Article 4 (2d) above). In the raid of the gay sex party in Surabaya in April 2017, besides forcing the men to undergo HIV tests, the police also confiscated condoms, mobile phones, and a flash drive containing pornographic videos, which led the men to be charged under the Pornography Law for possessing and showing pornographic materials. Similarly, not only was the striptease performance allegation upheld against the people involved, but they were also confronted with an accusation of commercial sexual activity. In the case of Jakarta's gay sex party in September 2020, nine individuals accused as the organisers reportedly officially became suspects because they arranged or organised the event, including renting the space, providing food, looking after the participants' belongings, and receiving a money transfer from the participants (BBC 2020). To provide further illustration, in the raid of Atlantis, 
both the hired strippers and the space provider (most likely the owner of the business) were reportedly charged under the Pornography Law, particularly Article 4. Any monetary transaction involved, although not for purchasing sexual services from any individual, was used to associate the event with Article 4 (2d), in which pornography services include "offering or promoting, both directly or indirectly, sexual services" (see earlier discussion). In Indonesia, sex work can be indirectly criminalised by both the Pornography Law and the KUHP (Butt and Lindsey 2018, p. 198). ${ }^{12}$

Under the Pornography Law, the sorting mechanism of public-private also haunts non-sexual activities, particularly HIV / / AIDS prevention public campaigns, which can easily be viewed as violating society's moral codes. A Human Rights Watch (2018) records how the police raids of gay events have invigorated fears of prosecution from HIV / AIDS outreach workers who promote safe-sex information and, to some extent, provide condoms and voluntary HIV tests to gay people in some 'hotspot' areas where gay men and other queer people hang out. Historically, as Boellstorff $(2005$, p. 127) has noted, gay Indonesians often "meet at 'hanging-out places' ... known in many parts of Indonesia as tempat ngeber (tempat means 'place'; ngeber is a gay language term for 'hang out)". Tempat ngeber usually encompass various public and civic spaces, including "parks, town squares, bridges, waterfronts, or bus station" (Boellstorff 2005, p. 128). ${ }^{13}$ Due to the recent crackdown on gay people, HIV / AIDS outreach workers have increasingly felt insecure and isolated (Human Rights Watch 2018, p. 43). This is caused by the closure of many gay hotspots and venues and the use of condoms as "evidence of gay prostitution" (Human Rights Watch 2018, p. 48), subsequently making both outreach workers and condom recipients susceptible to criminalisation. As seen throughout the analysis above, the potential criminalisation of gay people is not always be based only on their sexual orientation but can be further justified by the level of public-ness of their activities, involving the space where the activity takes place and also the particular objects, such as condoms, serving as evidence of commercial sex. Equally important to note here is that although tempat ngeber are situated in locations ordinarily construed as public, these spaces can also be hidden from public knowledge or view and organised according to subcultural knowledge and codes. For this reason, again, the boundaries between public and private are flexible and subject to an arbitrary determination.

The extensive criminalisation of non-sexual activities arising from the Pornography Law also extends to online spaces that are unable to escape the sorting mechanism of publicprivate. In September 2016, the Ministry of Communications and Information banned three gay networking applications, Grindr, Boyahoy, and Blued, along with other gay websites, after reportedly receiving reports from members of the public about an increase of 'LGBT campaigns' in digital platforms (Wijaya 2020, p. 160). Aidil Chendramata from the Ministry of Communication clearly justified this censorship with the argument that gay applications violated the Pornography Law (Yulius 2016). In a similar vein, in 2018, two men in Bandung, West Java, were arrested because they were the administrators of a Facebook group, Gay Bandung Indonesia. This time, the police did not charge them under the Pornography Law, but under the Information and Electronic Transactions Law (ITE Law) (Undang-Undang No. 11/2008 or Law No. 11/2008 on Information and Electronic Transactions), which forbids the distribution of materials that violate 'decency' (kesusilaan). Intriguingly, the accusation that the administrators circulated pornographic content and facilitated commercial sex was reportedly based on the sale of condoms and lubricant by the two men (Kumparan 2018; Nathaniel 2018). In one media report, the police argued that the basis for the arrest was not the individuals' sexual orientation but their 'public' conduct in violating decency (Nathaniel 2018). Although such allegations were certainly vague, the use of the ITE Law instead of the Pornography Law indicates another legal

12 (Butt and Lindsey 2018, p. 198) assert that "prostitution is not explicitly forbidden under Indonesian law". Nonetheless, the Criminal Code and other regulations, such as Law 21 of 2007 on the Eradication of Human Trafficking, can be used to penalise sex work (Butt and Lindsey 2018, p. 198).

13 For a more comprehensive discussion of gay public space in Indonesian gay culture, see (Boellstorff 2005, pp. 126-56). 
mechanism potentially deployed to prosecute specific sexual expressions engaging any type of commercial transaction and public space.

Certainly, all of the above accounts have demonstrated the persistent binary of publicprivate that determines what kinds of homosexual expressions and practices are susceptible to legal prosecution, and equally, the central role of space, monetary transactions, and the vague and arbitrarily-determined notion of 'public' in justifying the state's carceral governance of homosexuality.

Despite targeting public same-sex sexual behaviours through the law followed by the spectacle of prosecution by the media, I would argue that the Pornography Law has also contributed to the creation and solidification of socio-cultural meanings around same-sex sexual relations or intimacies. It has rendered 'homosexuality' and/or 'homosexual sex' as a sexual identity and sexual practices more intelligible and visible to the state and society in Indonesia. Apart from the explicit mention of 'homosexual sex' in the Pornography Law itself, the headlines of media reports on these gay arrests frequently used the term "pesta gay" (gay party) or "pesta seks gay" (gay sex party) [emphasis added] (Firmansyah 2020; Kholid 2017; Sidebang 2020). Connecting these media reports with the anti-LGBT media environment described earlier, the arrests and charges of gay individuals under the Pornography Law have continued to shape social meanings surrounding homosexuality and/or homosexual acts as an immoral act and an insatiable sexual practice that defies the public order and norms, making it subject to heightened surveillance and criminalisation. Moreover, as long as the term 'homosexual' sex remains on the books, the Pornography Law will always be available to be conveniently deployed to penalise gay people at any time.

\section{Conclusions}

This article has demonstrated the carceral governance of homosexuality. On the one hand, same-sex sexual acts are likely to become subject to prosecution when those acts blur the distinction between public and private. Such a determination is highly arbitrary as determined through the Pornography Law. On the other hand, as the Law has codified homosexual sex explicitly, the arrests of gay people, along with the anti-LGBT media environment and spectacle, have continued to shape social meanings surrounding homosexual identity and same-sex sexual acts. Connecting this carceral governance with the recent anti-LGBT media environment, it is not difficult to see how the spectacle of these gay arrests in the media has reified the idea that homosexual people or homosexual acts are morally-threatening, dangerous, and insatiable creatures/sexual practices (Yulius 2017a).

The analysis in this article brings forth two implications for further critical examination. First, instead of merely positioning Indonesia as a homophobic country, it is more meaningful to examine the ways in which homosexuality and/or homosexual behaviours are governed, managed, and even silenced in public to preserve the national culture and identity under the abstract notion of public order. Along with the Pornography Law, another example comes from the local bylaws in Padang Pariaman, West Sumatra introduced in 2018. This bylaw prohibits people from acting as 'waria', an Indonesian term for transgender woman, and exhibiting indecent conduct related to LGBT intimacies (Kampai 2018; The Jakarta Post 2018). As reported in the media, the Head of the Regional House of Representatives (Dewan Perwakilan Rakyat Daerah, DPRD) of Pariaman City, Fitri Nora, decreed that any LGBT-related expressions in a public space would be penalised if deemed disruptive to the 'public order' (ketertiban umum) [emphasis added] (Kampai 2018). Here, it is clear that the sorting mechanism of the public-private divide, along with the vague notion of 'public order', is deployed to control homosexual expressions and intimacies.

Second, it is also necessary to examine the impact of the Pornography Law on heterosexual people. Although this article does not aim to compare the Law's prosecutory impacts on homosexual and non-homosexual individuals, several cases hint that non-homosexual people are also susceptible to criminalisation due to the highly arbitrary determination of the public and the private. In August 2021, Indonesian female celebrity, Dinar Candy, was reportedly charged under the Pornography Law, mainly because she protested on the street 
against public activity restrictions during the COVID pandemic by wearing a bikini (CNN Indonesia 2021). Another example is the charge of Indonesian female celebrity, GA, and her male partner as suspects under the Pornography Law when their alleged sex tape leaked to the public "amid calls from activists over privacy protection" for them to be seen as victims rather than producers of pornography (The Jakarta Post 2020). For this reason, a line of inquiry can also be pursued to examine how and under what circumstances heterosexuality and/or heterosexual acts become susceptible to criminalisation under this Law and assess whether the Law has disproportionate impacts on gay people and cultures. Such critical evaluation can help to further define the contours of the carceral governance of sexuality in contemporary Indonesia.

Funding: This research received no external funding.

Institutional Review Board Statement: Not applicable.

Informed Consent Statement: Not applicable.

Acknowledgments: I would like to thank Jonathan Symons, Bruce Clezy, Dewi Anggraeni, David Roberts, Sydney Garcia, David Bridger, Graeme Aitken, Andrew Harding, Wina Indiarto, Firdhan Aria Wijaya, Lany Harijanti, Dyah Pitaloka, Ririn Radiawati, and Albert Wirya for their intellectual companionship, emotional support, and stimulating discussions throughout the writing process. I also thank the anonymous reviewers and the guest editors of this special issue-Aleardo Zanghellini and Kate Gleeson-for their keen eyes and sharp feedback. Rest in peace, love, and power Hauw Eng Ho (1964-2021).

Conflicts of Interest: The author declares no conflict of interest.

\section{References}

Allen, Pam. 2009. Women, Gendered Activism and Indonesia's Anti-Pornography Bill. Intersections: Gender and Sexuality in Asia and the Pacific. Issue 19. Published Electronically. February 27. Available online: http://intersections.anu.edu.au/issue19/allen.htm (accessed on 3 July 2021).

Barclay, Scott, Mary Bernstein, and Anna-Maria Marshall. 2009. The Challenge of Law: Sexual Orientation, Gender Identity, and Social Movements. In Queer Mobilisations: LGBT Activists Confront the Law. Edited by Scott Barclay, Mary Bernstein and Anna-Maria Marshall. New York and London: New York University Press, pp. 1-17.

Barker, Thomas. 2015. Sex on Indonesia's Screens. In Sex and Sexualities in Contemporary Indonesia. Edited by Linda Rae Bennett and Sharyn Graham Davies. London and New York: Routledge, pp. 253-272.

BBC. 2020. 'Pesta gay': Polisi Kenakan Pasal Muncikari dan Pornografi ke Kelompok LGBT, Pakar dan Aktivis Sebut 'Diskriminatif' dan 'Keliru'. BBC News. September 4. Available online: https:/ / www.bbc.com/indonesia/indonesia-54014777 (accessed on 3 July 2021).

Berlant, Lauren, and Michael Warner. 1998. Sex in Public. Critical Inquiry 24: 547-66. [CrossRef]

Bernstein, Elizabeth. 2018. Brokered Subjects: Sex, Trafficking, and The Politics of Freedom. Chicago: The University of Chicago Press.

Boellstorff, Tom. 2005. The Gay Archipelago: Sexuality and Nation in Indonesia. Princeton: Princeton University Press.

Butt, Simon. 2019. The Constitutional Court and Minority Rights. In Contentious Belonging. Edited by Greg Fealy and Ronit Ricci. Singapore: ISEAS, pp. 55-73.

Butt, Simon, and Tim Lindsey. 2018. Indonesian Law. Oxford: Oxford University Press.

Chua, Lynette. 2014. Mobilising Gay Singapore: Rights and Resistance in an Authoritarian State. Singapore: National University of Singapore Press.

CNN Indonesia. 2021. Protes Bikini Dinar Candy Berujung Jerat UU Pornografi. CNN Indonesia. August 6. Available online: https: //www.cnnindonesia.com/nasional/20210806074940-12-677115/protes-bikini-dinar-candy-berujung-jerat-uu-pornografi (accessed on 20 October 2021).

Cossman, Brenda. 2021. The New Sex Wars: Sexual Harms in the \#MeToo Era. New York: New York University Press.

Davies, Sharyn Graham, and Linda Rae Bennett. 2015. Introduction: Mapping Sex and Sexualities in Contemporary Indonesia. In Sex and Sexualities in Contemporary Indonesia. Edited by Linda Rae Bennett and Sharyn Graham Davies. London and New York: Routledge, pp. 1-25.

Duggan, Lisa. 2003. The Twilight of Equality? Neoliberalism, Cultural Politics, and the Attack on Democracy. Boston: Beacon Press.

Eng, David L. 2010. The Feeling of Kinship: Queer Liberalism and The Racialisation of Intimacy. Durham and London: Duke University Press.

Eng, David, Jack Halberstam, and Jose Esteban Munoz. 2005. Introduction: What's Queer about Queer Studies Now? Social Text 84-85: 1-17. [CrossRef] 
Firmansyah, M. Julnis. 2020. Panitia Berencana Buat Pesta Gay Ketujuh Jika Tak Digerebek Polisi. Tempo Website. September 3. Available online: https://metro.tempo.co/read/1382418/panitia-berencana-buat-pesta-gay-ketujuh-jika-tak-digerebek-polisi (accessed on 17 October 2021).

Foucault, Michel. 1978. The History of Sexuality Volume 1: An Introduction. New York: Pantheon Books.

Ghaziani, Amin, and Matt Brim. 2019. Queer Methods: Four Provocations for an Emerging Field. In Imagining Queer Methods. Edited by Amin Ghaziani and Matt Brim. New York: New York University Press, pp. 3-27.

Gleeson, Kate. 2007. Discipline, Punishment, and the Homosexuality in Law. Liverpool Law Review 28: 327-47. [CrossRef]

Gruber, Aya. 2020. The Feminist War on Crime. Oakland: University of California Press.

Halley, Janet, Prabha Kotiswaran, Rachel Rebouché, and Hila Shamir, eds. 2019. Preface. In Governance Feminism: Notes from The Field. Minneapolis and London: University of Minnesota Press, pp. ix-xxxviii.

Halperin, David M., and Trevor Hoppe, eds. 2017. The War on Sex. Durham and London: Duke University Press.

Human Rights Watch. 2018. "Scared in Public and Now No Privacy": Human Rights and Public Health Impacts of Indonesia's Anti-LGBT Moral Panic. New York: Human Rights Watch.

Human Rights Watch. 2020. Indonesia: Investigate Police Raid on 'Gay Party'. Human Rights Watch. September 7. Available online: https:/ / www.hrw.org/news/2020/09/07/indonesia-investigate-police-raid-gay-party (accessed on 3 July 2021).

Hutton, Jeff. 2017. Indonesia's Crackdown on Gay Men Moves from Bars into the Home. The New York Times. December 20. Available online: https: / / www.nytimes.com/2017/12/20/world/asia/indonesia-gay-raids.html (accessed on 3 July 2021).

Kampai, Jeka. 2018. LGBT Didenda Rp 1 Juta, Ini Bunyi Perda Pariaman Sumbar. Detik. November 29. Available online: https: //news.detik.com/berita/d-4322864/lgbt-didenda-rp-1-juta-ini-bunyi-perda-pariaman-sumbar (accessed on 10 July 2021).

Kholid, Idham. 2017. Polisi Gerebek Pesta Gay ‘The Wild One’ di Kelapa Gading. Detik. May 22. Available online: https://news.detik. com/berita/d-3507704/polisi-gerebek-pesta-gay-the-wild-one-di-kelapa-gading (accessed on 17 October 2021).

Kumparan. 2018. Polisi Tangkap Admin Akun Facebook Gay Bandung Indonesia. Kumparan. October 19. Available online: https:// kumparan.com/kumparannews/polisi-tangkap-admin-akun-facebook-gay-bandung-indonesia-1539935379404561316/full (accessed on 10 July 2021).

Lewis, Carolyn Herbst. 2021. Suburban Swing: Heterosexual Marriage and Spouse Swapping in the 1950s and 1960s. In Heterosexual Histories. Edited by Rebecca L. Davis and Michele Mitchell. New York: New York University Press, pp. 251-73.

Lindsay, Jennifer. 2011. Media and Morality: Pornography Post Suharto. In Politics and The Media in Twenty-First Century Indonesia. Edited by Krishna Sen and David T. Hill. London and New York: Routledge, pp. 172-95.

Lindsey, Tim. 2019. Minorities and Discrimination in Indonesia: The Legal Framework. In Contentious Belonging. Edited by Greg Fealy and Ronit Ricci. Singapore: ISEAS, pp. 36-54.

Listiorini, Dina. 2020. Online Hate Speech. Inside Indonesia. January 26. Available online: https://www.insideindonesia.org/onlinehate-speech (accessed on 5 October 2020).

Murtagh, Ben. 2013. Genders and Sexualities in Indonesian Cinema Constructing Gay, Lesbi and Waria Identities on Screen. New York: Routledge.

Nathaniel, Felix. 2018. Kontroversi Penangkapan Pengelola Akun Gay Bandung oleh Polisi. Tirto.id. October 24. Available online: https:/ / tirto.id/kontroversi-penangkapan-pengelola-akun-gay-bandung-oleh-polisi-c8qG (accessed on 10 July 2021).

Pausacker, Helen. 2008. Hot Debates. Inside Indonesia. December 14. Available online: https://www.insideindonesia.org/hot-debates (accessed on 4 July 2021).

Puar, Jasbir K. 2007. Terrorist Assemblages: Homonationalism in Queer Times. Durham and London: Duke University Press.

Raj, Senthorun, and Peter Dunne. 2021. Queering Outside the (Legal) Box: LGBTIQ People in the United Kingdom. In The Queer Outside in Law Recognising LGBTIQ People in the United Kingdom. Edited by Senthorun Raj and Peter Dunne. Cham: Palgrave Macmillan, pp. 1-19.

Rinaldo, Rachel. 2013. Mobilising Piety: Islam and Feminism in Indonesia. Oxford: Oxford University Press.

Robinson, Kathryn. 2015. Masculinity, Sexuality, and Islam. In Sex and Sexualities in Contemporary Indonesia. Edited by Linda Rae Bennett and Sharyn Graham Davies. London and New York: Routledge, pp. 51-68.

Rottenberg, Catherine. 2018. The Rise of Neoliberal Feminism. Oxford: Oxford University Press.

Rubin, Gayle S. 2007. Thinking Sex: Notes for a Radical Theory of the Politics of Sexuality. In Culture, Society and Sexuality: A Reader, Second Edition. Edited by Richard Parker and Peter Aggleton. London and New York: Routledge, pp. 150-87. First published 1984.

Sari, Dita Indah. 2006. Karena Kekuasaan Butuh Patriarkhi. Jurnal Perempuan 47: 7-16.

Sasono, Eric. 2004. Pornografi dalam Konteks Sensor Film di Indonesia. Jurnal Perempuan 38: 75-85.

Sawitri, Cok. 2006. Tolak Kebijakan I Belog Yang Mengubur Dirinya. Jurnal Perempuan 47: 41-56.

Sidebang, Flori. 2020. Polisi akan Gelar Rekonstruksi Kasus Pesta Gay. Republika Website. September 3. Available online: https: //www.republika.co.id/berita/qg2bxm335/polisi-akan-gelar-rekonstruksi-kasus-pesta-gay (accessed on 17 October 2021).

Smith, Miriam. 2017. Homonationalism and the Comparative Politics of LGBTQ Rights. In LGBTQ Politics. Edited by Marla Brettschneider, Susan Burgess and Christine Keating. New York: New York University Press, pp. 458-76.

Suryakusuma, Julia I. 1996. The State and Sexuality in New Order Indonesia. In Fantasising the Feminine in Indonesia. Edited by Laurie J. Sears. Durham and London: Duke University Press, pp. 92-119.

Tang, Shawna. 2017. Postcolonial Lesbian Identities in Singapore: Re-Thinking Global Sexualities. Oxon: Routledge. 
Tempo. 2010. Penggelar Q! Film Festival Dilaporkan ke Polisi. Tempo. October 1. Available online: https://metro.tempo.co/read/2818 65/penggelar-q-film-festival-dilaporkan-ke-polisi (accessed on 4 July 2021).

The Jakarta Post. 2018. Indonesian City to Fine LGBT for Being 'Public Nuisance'. The Jakarta Post. November 30. Available online: https://www.thejakartapost.com/news/2018/11/30/indonesian-city-to-fine-lgbt-for-being-public-nuisance.html (accessed on 10 July 2021).

The Jakarta Post. 2020. Policy Name Two New Suspects in Leaked Celebrity Sex Tape Case. The Jakarta Post. December 30. Available online: https: / www.thejakartapost.com/news/2020/12/29/police-name-two-new-suspects-in-leaked-celebrity-sex-tape-case. html (accessed on 20 October 2021).

Thomas, Jerry D. 2017. Queer Sensibilities and Other Fagchild Tools. In LGBTQ Politics. Edited by Marla Brettschneider, Susan Burgess and Christine Keating. New York: New York University Press, pp. 394-413.

UNDP and USAID. 2014. Being LGBT in Asia: Indonesia Country Report. Bangkok: UNDP.

Van Wichelen, Sonja. 2010. Religion, Politics, and Gender in Indonesia: Disputing the Muslim Body. London: Routledge.

Warner, Michael. 2002. Publics and Counterpublics. New York: Zone Books.

Westbrook, Laurel. 2021. Unliveable Lives: Violence and Identity in Transgender Activism. Oakland: University of California Press.

Widyawati, Vivi. 2004. Kata dan Makna. Jurnal Perempuan 47: 111-16.

Widyawati, Vivi. 2006. Perempuan versus Parlemen. Jurnal Perempuan 47: 17-30.

Wiegman, Robyn. 2019. Eve's Triangles: Queer Studies Besides Itself. In Reading Sedgwick. Edited by Lauren Berlant. Durham and London: Duke University Press, pp. 242-73.

Wieringa, Saskia. 2019. Is the Recent Wave of Homophobia in Indonesia Unexpected? In Contentious Belonging. Edited by Greg Fealy and Ronit Ricci. Singapore: ISEAS, pp. 113-32.

Wijaya, Hendri Yulius. 2019. Localising Queer Identities: Queer Activisms and National Belonging in Indonesia. In Contentious Belonging. Edited by Greg Fealy and Ronit Ricci. Singapore: ISEAS, pp. 133-51.

Wijaya, Hendri Yulius. 2020. Intimate Assemblages; The Politics of Queer Identities and Sexualities in Indonesia. Singapore: Palgrave Macmillan.

Wijaya, Hendri Yulius, and Sharyn Graham Davies. 2019. Lesbian and Gay Activism and Indonesia's Unfulfilled Promise of Democracy. In Activists in Transition: Progressive Politics in Democratic Indonesia. Edited by Thushara Dibley and Michele Ford. Ithaca: Cornell University Press, pp. 153-70.

Yulius, Hendri. 2016. Double Standards: The Defining of Homosexuality as Pornographic in Indonesia. The Jakarta Post. October 21. Available online: https://www.thejakartapost.com/academia/2016/10/21/double-standards-the-defining-of-homosexualityas-pornographic-in-indonesia.html (accessed on 10 July 2021).

Yulius, Hendri. 2017a. Moral Panic and The Reinvention of LGBT. Indonesia at Melbourne. May 17. Available online: https:// indonesiaatmelbourne.unimelb.edu.au/moral-panic-and-the-reinvention-of-lgbt/ (accessed on 3 July 2021).

Yulius, Hendri. 2017b. Constitutional Court Ruling a Reminder That the State Is Not Uniform. Indonesia at Melbourne. December 19. Available online: https://indonesiaatmelbourne.unimelb.edu.au/constitutional-court-ruling-a-reminder-that-the-state-is-notuniform/ (accessed on 3 July 2021).

Yulius, Hendri, Shawna Tang, and Baden Offord. 2018. The Globalisation of LGBT Identity and Same-Sex Marriage as a Catalyst of Neo-Institutional Values: Singapore and Indonesia in Focus. In Global Perspectives on Same-Sex Marriage. Edited by Bronwyn Winter, Maxime Forest and Rejane Senac. Cham: Palgrave Macmillan, pp. 171-96.

Zanghellini, Aleardo. 2013. Sodomy Laws and Gender Variance in Tahiti and Hawai'i. Laws 2: 51-68. [CrossRef] 